\title{
EVALUATION OF SHILAJATU FOR IMPROVEMENT IN QUALITY OF LIFE IN PATIENTS OF DIABETES MELLITUS
}

\section{Neha Lamba}

${ }^{1}$ Ayurvedic Medical Officer, ESI Hospital, Jalandhar, Punjab

\section{ABSTRACT}

As per WHO, in South-east Asia region alone 96 million people are estimated to be suffering from diabetes. Due to sedentary lifestyle and stress full nature of work, associated risk factors such as being overweight or obese, the number of diabetic patients is increasing. Diabetes is an important cause of blindness, kidney failure, lower limb amputation and other longterm consequences that impact on quality of life significantly. Continuous research is being done by scientists of various fields in order to achieve an effective cure of the disease and to improve quality of life. A great deal of work has also been done by Ayurvedic research scholars on various herbal and mineral drugs to find an effective treatment for diabetes generally reffered to as Prameha. Shilajatu is one such drug which has been described for the management of Prameha in Ayurveda texts. The present study was conducted to evaluate the efficacy of Shilajatu in the improving the quality of life in patients of Prameha. Twenty two diabetic patients were selected for the study. The results were assessed in terms of symptomatic relief on the basis of scoring system, as per the Questionnaire on Quality of Life. Statistically highly significant improvement $(p<0.001)$ was observed on physical domain. Statistically significant improvement was observed on psychological domain with $p<0.001$. In terms of Social Relationships Domain also, highly significant improvement, with $p<0.001$ was observed. Highly significant improvement was observed in overall quality of 
life statistically with $p<0.001$. The study revealed that Shilajatu can be used as a drug in the management of Prameha to improve the quality of life of patients.

KEY WORDS: Diabetes, Prameha, quality of life, Shilajatu, WHO-QOL-BREF

\section{INTRODUCTION}

Diabetes mellitus is emerging as one of the most dynamic health hazard which ultimately affects all the body organs acting as a silent killer. No longer a disease of predominantly rich nations, the prevalence of diabetes is steadily increasing everywhere, most markedly in the world's middle-income countries. As per WHO, Diabetes caused 1.5 million deaths in 2012 alone. Higher-than-optimal blood glucose level was responsible for an additional 2.2 million deaths as a result of increased risks of cardiovascular and other diseases, thus making a total of 3.7 million deaths related to blood glucose levels in 2012. Many of these deaths (43\%) occurred under the age of $70 . \ln 2014$, 422 million people in the world had diabetes - a prevalence of $8.5 \%$ among the adult population. In Southeast Asia region only 96 million people are estimated to be suffering from diabetes. (1) Due to sedentary lifestyle and stress full nature of work, associated risk factors such as being overweight or obese are increasing. Diabetes is an important cause of blindness, kidney failure, lower limb amputation and other long-term consequences that impact on quality of life significantly. Unfortunately, in many settings the lack of effective policies to create supportive environments for healthy lifestyles and the lack of access to quality health care means that the prevention and treatment of diabetes, particularly for people of modest means, are not being pursued. Government of India has also called upon to look forward to Yoga for control of diabetes and improvement in lifestyle. (2) Ayurveda has always contributed to the health needs of people since ages. It has a rich treasure of safe materia medica which provides a promising field of research in terms of health benefits and improvement in lifestyle, especially in view of its vast treasury of drugs. Shilajatu is one such drug the use of which has been widely advocated for madumeha ( Diabetes mellitus) in ancient texts.(3) Shilajatu can be used either alone or in combination with other herbo min- eral formulations, after its proper purification process. (4) Several studies have been conducted on Shilajatu for its anti-diabetic effects, but none has been done to evaluate its effect on Quality of Life. In the most general terms, quality of life may be thought of as a multidimensional construct incorporating an individual's subjective perception of physical, emotional, and social well-being, including both a cognitive component (satisfaction) and an emotional component (happiness.) Hence, an attempt has been made to study the effect of Shilajatu which has been reported to possess hypoglycaemic property (5) on Quality of Life of patients of madhumeha using the WHOQOL-BREF questionnaire.

\section{MATERIALS AND METHODS}

Selection of subject:- 22 patients attending the OPD of the Institution's Hospital were selected in the age group of 25 years to 70 years irrespective of race, caste and religion. It was an observational trial with Single group only.

\section{Inclusion criterion:}

Patients willing for the trial with Fasting Blood Sugar between $126 \mathrm{mg} / \mathrm{dl}-200 \mathrm{mg} / \mathrm{dl}$ and only uncomplicated cases of Type II Diabetes Mellitus were included in the trial.

\section{Exclusion criterion:}

Patients presenting with complications like severe renal disease, retinopathy, ischemic heart disease, severe hypertension and those suffering from type I Diabetes Mellitus were excluded from the trial.

\section{Laboratory Analysis:}

1. Blood examination:- fasting Blood Sugar, Post prandial blood sugar, $\mathrm{HbA}_{1 \mathrm{c}}, \mathrm{Hb} \% \mathrm{gm}$, TLC, DLC, ESR, S.urea, S. creatinine, Lipid profile

\section{Urine Sugar}

\section{Questionnaire}

WHOQOL-BREF is an abbreviated generic Quality of Life Scale developed through the World Health Organization. The purpose of this tool is to assess quality of life (QOL) within the context of an individual's culture, value systems, personal goals, standards and concerns. (6) WHOQOL-BREF is the short version of the WHOQOL 100 and is recommended for use when time is restricted or the burden on the respondent 
needs to be minimized. This survey has been used in large epidemiological studies and clinical trials. It is a self-report questionnaire that contains 26 items and addresses 4 QOL domains: physical health (7 items), psychological health (6 items), social relationships (3 items) and environment (8 items). Two other items measure overall QOL and general health. Items are rated on a 5-point Likert scale (low score of 1 to high score of 5) to determine a raw item score. Subsequently, the mean score for each domain is calculated, resulting in a mean score per domain that is between 4 and 20 . Finally, this mean domain score is then multiplied by 4 in order to transform the domain score into a scaled score, with a higher score indicating a higher QOL. When transformed by multiplying $\mathrm{x} 4$, each domain score is then comparable with the scores used in the original WHOQOL-100.

\section{Method of Study}

I. IEC \& Consent:- Approval from the Institutional Ethics Committee (IEC) was taken prior to begin with this study vide No. IEC/2013/355 dated 10-06-2013. Written \& informed consent of the patients was taken before their registration for the study.

II. Patient Information Sheet \& CRF:-All the patients were given an information sheet stating all the details of the study protocol, benefits of the trial \& any expected side effects. A clinical Research proforma was prepared to note down all the details of the patients and their disease profile.

III. Drug:- The trial drug namely, Shuddha Shilajatu was procured from the Charak Govt. Ayurvedic Pharmacy, Paprola.

IV. Administration of Drug:- The trial drug Shuddha Shilajatu was given by oral route in the dose of $250 \mathrm{mg}$ twice a day for 28 days with plain water.

V. Assessment:- Before and after treatment total two assessments were carried out. Criterion of assessment was based on the scoring of Questionnaire on Quality of Life, which included Physical Domain, Psychological Domain, Social Relationships Domain, Environment Domain.

Statistical Analysis:-The obtained data was analyzed statistically and expressed in terms of mean, standard deviation ( \pm SD) and standard error ( \pm SE). Appropriate ' $t$ ' test was applied to observe the significance of results obtained after treatment. The data was analysed using the "spss software" of statistics.

\section{OBSERVATIONS}

Of the total 22 subjects enrolled, 18 completed the study. Four patients did not turn up for the follow up and were considered drop out. Maximum number of patients $36.36 \%$ was in age group of $41-50$ years, $54.54 \%$ were male patients, $59.09 \%$ were Graduates, $63.63 \%$ belonged to Middle class. $45.45 \%$ patients were in government service while $40.90 \%$ were housewives, $72.72 \%$ took mixed diet, $36.36 \%$ patients had BMI between 25-30 followed by $27.27 \%$ BMI between 20-24.9. of the total patients $45.45 \%$ were of Vata Kaphaja Prakriti, 27.27\% each were of Vata Pittaja and Pitta Kaphaja Prakriti. 54.54\% patients had diabetes mellitus for less than one year. In $50 \%$ cases a positive family history of diabetes was present. The Blood pressure of $40.90 \%$ patients was within normal limits, $36.36 \%$ of patients were pre hypertensive while $27.72 \%$ of patients reported to be stage-I hypertensive. $59.09 \%$ patients in the study reported to have increased appetite. In the present study, only $04.54 \%$ patients were taking strenuous physical activity, while $63.63 \%$ patients had mild physical activity. (Table-1)

\section{RESULTS}

The effect of therapy was assessed on the basis of observations of subjective symptoms, laboratory investigations and the questionnaire on quality of life (WHO-QOL-BREF). A Questionnaire on Quality of Life (WHO-QOL-BREF) was given to each patient to assess the quality of Life, and its impact on their Physical, Psychological and social life and well-being. Statistical analysis (Table 2) showed highly significant improvement with mean percentage difference of $28.85(p<0.001)$ in their Physical Domain. Mean percentage difference in data obtained prior to treatment and after treatment in Psychological domain was 24.83 ( $p<0.001)$ thus showing highly significant improvement. The third aspect, Environmental domain was analysed in the WHO-QOL-BREF. Highly significant score with $p<0.001$ was observed on it with mean percentage difference in data obtained prior to treatment and after treatment being 6.52. Social Relationships Domain was also analysed according to the questions as stated in the questionnaire and the result was found to be highly significant ( $p$ $<0.001$ ) with mean percentage difference of 13.18 . 
Based on this result, it could be inferred that the patients responded well to the treatment and there was a marked improvement in their Quality of Life. This part of the result also indicated that the treatment was effective in improving the psychological and social life and had a significant outcome on the well-being of the patients in relation to their surrounding environment.

\section{DISCUSSION}

The present study was undertaken to evaluate the effect of Shilajatu in the improvement in quality of life of patients suffering from type II Diabetes Mellitus. The outcome of the study showed ample evidence of shilajatu acting as promoter of good quality of life in patients and of type II Diabetes Mellitus. There is a positive association between high levels of perceived quality of life and good glycemic control, especially when quality of life is assessed by disease-specific measures that capture relevant symptoms and feelings, and as long as good control is not accompanied by significant increases in treatment burden or hypoglycaemia. (7)The four domains namely, Physical domain, Psychological domain, Social Relationships domain and Environment domain is a complex of 26 questions and the patient responses to these are simplified in to four domains. The first domain comprises questions regarding Physical pain which hampers daily activity, requirement of any medication for the same, sleep pattern, daily activity and capacity for work and constitute the physical domain. Bala and samhanana are the main factors that can be analysed from this domain. The ancient treatise of Charak Samhita mentions that Shilajatu possesses the property of being 'dehadardhyakara'(8) i.e. it is able to improve consistency and quality of tissue elements, which counteracts the shithilta produced in the body due to Prameha which is an important factor comprised in physical domain.

Enjoyment and inspiration in life, ability to concentrate, inspiration, to accept your bodily appearance, satisfaction with one self, occurrence of negative feelings such as blue mood, despair, anxiety, depression constitute psychological domain. Satisfaction in personal life, peer support, sexual life satisfaction constitutes the Social Relationships domain. Feeling of safety in daily life, healthy physical environment, monetary needs, information technology, enjoyment and leisurely activity, access to health services, conditions of living space, transportation constitute Environment domain. There is evidence that certain interventions, including the administration of hypoglycemic agents, education and counselling interventions targeted to control diabetes, can improve both glycemic control and quality of life in people with diabetes. (9) Shilajatu may be associated with correction of blood glucose level and lipid regulation in circulation. Experimental studies reveal that Shilajatu may be associated with phenomenon of reducing direct sugar and lipid from gut, thereby affecting the overall metabolic syndrome along with dyslipidemia.(10) It may have the potential of reducing cellular sensitivity towards circulating insulin and some potential of correcting dyslipidemia at hepatic level. However, at this level it is difficult to verify and can only be represented as hypothesis in view of results seen. From this clinical study and the data generated from it, a hypothesis can be postulated that Shilajatu possesses potential hypoglycemic activity, which in turn improves the quality of life of patients suffering from type II Diabetes mellitus. The effect of the therapy on the Quality of Life was significant as assessed by WHO-QOLBREF scoring (Table 3). The overall feeling of well being was improved in the patients as per WHO questionnaire. Newly diagnosed patients \& those having FBS $<200 \mathrm{mg} / \mathrm{dl}$ can be advised the intake of Shilajatu along with life style modifications.

\section{CONCLUSION}

In the present study Shilajatu was evaluated for its efficacy in improving the quality of life of patients of Diabetes mellitus II. The drug showed significant improvement in subjective symptoms including the quality of life, physical well being, psychological and social well-being as well as environmental well being. However, further research to elucidate its exact mechanism of action and studies over animal models to validate the claim are required.

\section{REFERENCES}

1. Global Report on Diabetes, WHO, (Last accessed on 2016 August 1) available from http://apps.who. int/iris/bitstream/10665/204871/1/9789241565257 eng.pdf

2. Available from http://www.dnaindia.com/india/ report-modi-urges-the-nation-to-share-their-experiences-on-how-yoga-can-mitigate-diabetes-2228094 last accessed on 2016, august 2

3. Shastri Ambikadutt, Susruta Samhita edited with Ayurveda tatva sandipika Hindi Commentary, Chikitsa Sthana $13^{\text {th }}$ chapter, Madhumeha Chikitsa, Chaukhambha Sanskrit Sansthan, Varanasi, 
reprint edition; 2007. p. 64

4. Sadananda Sharma, Ras Tarangini, commentary by Haridatta Shastri, edited P. Kashinath Shastri, $22^{\text {nd }}$ Chapter, Mishralohavigyaniya $11^{\text {th }}$ edition, Motilal Banarsidas; 2009, p. 586

5. S. Bhattacharya, Shilajit attenuates streptozotocin induced diabetes mellitus and decrease in pancreatic islet superoxide dismutase activity in rats, Phytotherapy Research Volume 9. Issue 1, Article first published online: 20 JAN 2006)

6. WHO-QOL, Available from http://www.who.int/ mental health/media/en/76.pdf) (http://www.who. int/substance abuse/research tools/en/english whoqol.pdf Last accessed on 2016 August 2

7. Richard R. Rubin, Diabetes and Quality of Life, Available from http://journal.diabetes.org/diabetesspectrum/00v13n1/pg21.htm, last accessed on 2016, August 10

8. Shastri Kashinath \& Gorakhnath Chaturvedi, Charaka Samhita of Agnivesha elaborated Vidyotini Hindi commentary, Chikitsa sthana $1^{\text {st }}$ chapter Karpratichiya Rasayanpada, Chaukhambha Bharati Sansthan, Varanasi, reprint edition; 2005. p. 45.

9. Axel Hirsch, Diabetes Care in Germany: New Roles for Professionals and Patients, Available from http:// journal.diabetes.org/diabetesspectrum/00v13n1/ pg3.htm, last accessed on 2016, August 10.

10. Trivedi N A, Mazumdar B, Bhatt J D, Hemavathi K G. Indian J Pharmacol 2004 [cited 2014 Apr 24];36:373-6. Available from: http://www.ijp-online. com/text.asp?2004/36/6/373/13510 
Table 1: Demographic Observations

\begin{tabular}{|c|c|c|}
\hline Factor & Observation & $\begin{array}{l}\text { No. of Patients } \\
\text { (Percentage) }\end{array}$ \\
\hline Age group & $41-50$ yrs & $36.36 \%$ \\
\hline Sex & Males & $54.54 \%$ \\
\hline Education & Graduates & $59.09 \%$ \\
\hline Socio-Economic Status & Middle class & $63.63 \%$ \\
\hline \multirow[t]{2}{*}{ Occupation } & Government Service & $45.45 \%$ \\
\hline & Housewives & $40.90 \%$ \\
\hline Dietary Habit & Mixed diet & $72.72 \%$ \\
\hline \multirow[t]{2}{*}{ BMI } & $25-30$ & $36.36 \%$ \\
\hline & $20-24.9$ & $27.27 \%$ \\
\hline \multirow[t]{3}{*}{ Blood Pressure } & Normal & $40.90 \%$ \\
\hline & Pre HTN & $36.36 \%$ \\
\hline & Stage-1 & $22.72 \%$ \\
\hline $\begin{array}{l}\text { Family History of Diabetes } \\
\text { mellitus }\end{array}$ & Present & $50 \%$ \\
\hline Appetite & Increased & $59.09 \%$ \\
\hline \multirow[t]{3}{*}{ Prakriti } & Vata-Pitta & $27.27 \%$ \\
\hline & Pitta-Kapha & $27.27 \%$ \\
\hline & Kapha-Vata & $45.45 \%$ \\
\hline \multirow[t]{3}{*}{ Physical Activity } & Strenuous & $04.54 \%$ \\
\hline & Moderate & $31.81 \%$ \\
\hline & Mild & $63.63 \%$ \\
\hline
\end{tabular}




\begin{tabular}{|l|l|l|}
\hline \multirow{5}{*}{ Subjective symptoms } & Prabhuta Mutrata & $72.72 \%$ \\
\cline { 2 - 3 } & Pipasa & $72.72 \%$ \\
\cline { 2 - 3 } & Kshudha & $50.00 \%$ \\
\cline { 2 - 3 } & Shaithilya & $72.72 \%$ \\
\cline { 2 - 3 } & Karpada Suptata & $36.36 \%$ \\
\cline { 2 - 3 } & Karpada Daha & $13.63 \%$ \\
\cline { 2 - 3 } & Pindiko Udveshtana & $18.18 \%$ \\
\cline { 2 - 3 } & Mukha Sosha & $72.72 \%$ \\
\cline { 2 - 3 } & Sandhi Shoola & $31.81 \%$ \\
\hline
\end{tabular}

Table 2: Effect of therapy on WHO-QOL-BREF Score

\begin{tabular}{|c|c|c|c|c|c|c|c|c|}
\hline \multirow{2}{*}{$\begin{array}{l}\text { S. } \\
\text { No. }\end{array}$} & \multirow{2}{*}{ Criteria } & \multicolumn{2}{|l|}{ Mean } & \multirow{2}{*}{$\begin{array}{l}\text { \%age } \\
\text { Diff. }\end{array}$} & \multirow{2}{*}{ SD+ } & \multirow{2}{*}{$\mathrm{SE}+$} & \multirow[t]{2}{*}{$\mathrm{t}$} & \multirow{2}{*}{$\mathrm{p}$} \\
\hline & & BT & AT & & & & & \\
\hline 1 & Physical Domain & 79.33 & 102.22 & 28.85 & 11.21 & 2.64 & 8.66 & $<0.001$ \\
\hline 2 & $\begin{array}{l}\text { Psychological } \\
\text { Domain }\end{array}$ & 68.89 & 86.00 & 24.83 & 12.63 & 2.98 & 5.75 & $<0.001$ \\
\hline 3 & $\begin{array}{l}\text { Social Relationships } \\
\text { Domain }\end{array}$ & 40.44 & 45.78 & 13.18 & 3.36 & 0.79 & 6.73 & $<0.001$ \\
\hline 4 & $\begin{array}{l}\text { Environment } \\
\text { Domain }\end{array}$ & 112.44 & 119.78 & 6.52 & 6.76 & 1.59 & 4.60 & $<0.001$ \\
\hline
\end{tabular}

\section{Table 3: WHO-QOL-BREF SCORE}

Score: 1 - very poor; 2- poor; 3- neither poor nor good; ; 4- good; 5- very good 


\begin{tabular}{|c|c|c|c|c|c|c|c|c|c|c|}
\hline \multirow{2}{*}{$\begin{array}{l}\text { S.No } \\
1\end{array}$} & \multirow{2}{*}{$\begin{array}{l}\text { Question } \\
\text { How would you rate your quality of life? }\end{array}$} & \multicolumn{4}{|l|}{ BT } & \multicolumn{5}{|c|}{ AT } \\
\hline & & $1 \mid 2$ & 23 & $\begin{array}{llll}3 & 4\end{array}$ & 5 & 1 & 2 & 3 & 4 & 5 \\
\hline \multicolumn{11}{|c|}{$\begin{array}{l}\text { Score: 1- very dissatisfied; 2-Dissatisfied; 3- neither Sat nor Dissat; ; 4-Sat; 5- very } \\
\text { Sat. }\end{array}$} \\
\hline & & \multicolumn{4}{|l|}{ BT } & \multicolumn{5}{|c|}{ AT } \\
\hline 2. & How satisfied are you with your health? & $1 \mid 2$ & 23 & $\begin{array}{llll}3 & 4\end{array}$ & 5 & 1 & 2 & 3 & 4 & 5 \\
\hline \multicolumn{11}{|c|}{ Score: 1 - not at all; 2- a little; 3- moderate amount; ; 4- very much; 5- extremely } \\
\hline & & \multicolumn{4}{|l|}{ BT } & \multicolumn{5}{|c|}{ AT } \\
\hline 3 & $\begin{array}{l}\text { To what extent do you feel that physical pain } \\
\text { prevents you from doing what you need to do? }\end{array}$ & \begin{tabular}{l|l}
1 & 2 \\
\end{tabular} & \begin{tabular}{|l|l|l}
2 & 3
\end{tabular} & \begin{tabular}{l|l}
3 & 4
\end{tabular} & 5 & 1 & 2 & 3 & 4 & 5 \\
\hline 4. & $\begin{array}{l}\text { How much do you need any medical treatment } \\
\text { to function in your daily life? }\end{array}$ & & & & & & & & & \\
\hline 5. & How much do you enjoy life? & & & & & & & & & \\
\hline 6. & $\begin{array}{l}\text { To what extent do you feel your life to be } \\
\text { meaningful? }\end{array}$ & & & & & & & & & \\
\hline 7. & How well are you able to concentrate & & & & & & & & & \\
\hline 8. & How safe do you feel in your daily life? & & & & & & & & & \\
\hline 9. & How healthy is your physical environment? & & & & & & & & & \\
\hline \multicolumn{11}{|c|}{ Score: 1- not at all; 2- a little; 3 - Moderately; ; 4- Mostly; 5- completely } \\
\hline & & \multicolumn{4}{|l|}{ BT } & \multicolumn{5}{|c|}{ AT } \\
\hline 10. & Do you have enough energy for everyday life? & \begin{tabular}{l|l}
1 & 2 \\
\end{tabular} & \begin{tabular}{l|l}
2 & 3
\end{tabular} & \begin{tabular}{|l|l}
3 & 4 \\
\end{tabular} & 5 & 1 & 2 & 3 & 4 & 5 \\
\hline 11. & Are you able to accept your bodily appearance? & & & & & & & & & \\
\hline 12. & Have you enough money to meet your needs? & & & & & & & & & \\
\hline 13. & $\begin{array}{l}\text { How available to you is the information that you } \\
\text { need in your day to day day? }\end{array}$ & & & & & & & & & \\
\hline 14. & To what extent do you have the opportunity for & & & & & & & & & \\
\hline
\end{tabular}


leisure activities?

Score: 1- very poor; 2- poor; 3- neither poor nor good; ; 4- good; 5- very good

\begin{tabular}{|c|c|c|c|c|c|c|c|c|c|c|c|}
\hline & & BT & & & & & & & & & \\
\hline 15. & How well are you able to get around? & 1 & 2 & 3 & 4 & 5 & 1 & 2 & 3 & 4 & 5 \\
\hline
\end{tabular}

Score: 1- very dissatisfied; 2-Dissatisfied; 3- neither Sat nor Dissat; ; 4-Sat; 5- very Sat.

\begin{tabular}{|c|c|c|c|c|c|c|c|c|c|c|c|}
\hline & & B] & & & & & $\mathrm{A}^{\prime}$ & & & & \\
\hline 16. & How satisfied are you with your sleep? & 1 & 2 & 3 & 4 & 5 & 1 & 2 & 3 & 4 & 5 \\
\hline 17. & $\begin{array}{l}\text { How satisfied are you with your ability to } \\
\text { perform your daily living activities? }\end{array}$ & & & & & & & & & & \\
\hline 18. & $\begin{array}{l}\text { How satisfied are you with your capacity for } \\
\text { work? }\end{array}$ & & & & & & & & & & \\
\hline 19. & How satisfied are you with yourself? & & & & & & & & & & \\
\hline 20. & $\begin{array}{l}\text { How satisfied are you with your personal } \\
\text { relationship? }\end{array}$ & & & & & & & & & & \\
\hline 21. & How satisfied are you with our sex life? & & & & & & & & & & \\
\hline 22. & $\begin{array}{l}\text { How satisfied are you with the support you get } \\
\text { from your friends? }\end{array}$ & & & & & & & & & & \\
\hline 23. & $\begin{array}{l}\text { How satisfied are you with the conditions of } \\
\text { your living place? }\end{array}$ & & & & & & & & & & \\
\hline 24. & $\begin{array}{l}\text { How satisfied are you with your access to health } \\
\text { services? }\end{array}$ & & & & & & & & & & \\
\hline 25. & How satisfied are you with your transport? & & & & & & & & & & \\
\hline & 1- very poor; 2- poor; 3- neither poor nor good; ; 4 & & & & & & & & & & \\
\hline & & B] & & & & & A & & & & \\
\hline 26. & $\begin{array}{l}\text { How often do you have negative feelings such } \\
\text { as blue mood, despair, anxiety, depression? }\end{array}$ & 1 & 2 & 3 & 4 & 5 & 1 & 2 & 3 & 4 & 5 \\
\hline
\end{tabular}




\section{SCORING OF THE WHOQOL-BREF}

The WHOQOL-BREF (Field Trial Version) produces four domain scores. There are also two items that are examined separately: question 1 asks about an individual's overall perception of quality of life and question 2 asks about an individual's overall perception of his or her health. Domain scores are scaled in a positive direction (i.e. higher scores denote higher quality of life). The mean score of items within each domain is used to calculate the domain score. Mean scores are then multiplied by 4 in order to make domain scores comparable with the scores used in the WHOQOL-100, and subsequently transformed to a 0-100 scale, using the formula above. (WHOQOL user Manual, Appendix 10). A method for the manual calculation of individual scores is below:

Physical domain= $((6-\mathrm{Q} 3)+(6-\mathrm{Q} 4)+\mathrm{Q} 10+\mathrm{Q} 15+\mathrm{Q} 16+\mathrm{Q} 17+\mathrm{Q} 18) \mathrm{x} 4$.

Psychological domain= (Q5 + Q6 + Q7 + Q11 + Q19+ (6-Q26))x4.

Social Relationships domain $=(\mathrm{Q} 20+\mathrm{Q} 21+\mathrm{Q} 22) \times 4$.

Environment domain= $(\mathrm{Q} 8+\mathrm{Q} 9+\mathrm{Q} 12+\mathrm{Q} 13+\mathrm{Q} 14+\mathrm{Q} 23+\mathrm{Q} 24+\mathrm{Q} 25) \mathrm{x} 4$.

Where more than $20 \%$ of data are missing from an assessment, the assessment should be discarded. Where up to two items are missing, the mean of other items in the domain is substituted. 